\title{
The State of Application of Electronic Education System in Azerbaijan
}

\author{
Ophelya Mazanova ${ }^{1}$ Arzu Huseynova ${ }^{2}$ \\ ${ }^{1}$ Assistant Professor, UNEC (Azerbaijan State University of Economics), Electronic Management Center \\ ${ }^{2}$ Professor, UNEC (Azerbaijan State University of Economics), Digital Economy and ICT chair \\ *Corresponding Author: arzu_huseynova@unec.edu.az \\ Copyright $\odot 2020$ by authors, all rights reserved. Authors agree that this article remains permanently open access \\ under the terms of the Creative Commons Attribution License 4.0 International License
}

Article History: Received: 10 November 2020; Revised 12 January 2021 Accepted: 27 January 2021; Published online: 5 April 2021

\begin{abstract}
The article deals with the application of electronic management systems in the higher education system, the increase of electronic resources, the ways to ensure employment and convenience for teachers and students, the implementation of social reading programs apart from traditional lectures in the training classes, provision of information security, and elimination of electronic backwardness. The article also discusses the use analysis of electronic education system in Azerbaijani higher education institutions and evaluation methods of its economic effectiveness. Created a questionnaire to analyze e-learning, traditional training, and mixed learning. The questionnaire covers 20 electronic resources. The level of use of electronic means in the training process was analyzed based on the survey questionnaire. Survey questionnaire was conducted between teachers and students of higher education institutions. Cluster, regression, SWOT, and PEST analysis methods were used in the process of query processing. As a result, it was recommended to develop a strategy for the electronic education system and to develop a human resources training system for innovative Technologies.
\end{abstract}

Keywords: LMS, SWOT, PEST, Cluster, Electronic Resources.

\section{Introduction}

Establishment of Information Society in Azerbaijan is one of the main priorities of the state policy. The main tasks of the formation of information society are the creation of legal bases of information and knowledge society, the development of human factor, the right of citizens to receive, disseminate and use information, the formation of electronic government, electronic commerce, strengthening of economic, social and intellectual potential of the country, establishment of information and knowledge-based, competitive economy, creation of modern information and communication infrastructure, formation of uniform national electronic information space, implementation of electronic governance systems in higher education system, increase of electronic resources, determining the ways to ensure employment and convenience for teachers and students, implementation of social reading programs apart from traditional lectures in the training classes, provision of information security, and elimination of electronic backwardness.

The tendency of global informatization of the society is directly related to the development of educational institutions. This requires the creation of a continuing education system that ensures that everyone has access to quality basic education, as well as to the wishes and demands of everyone at any time and place, from the point of view of the availability of education. It is important to use electronic education (e-education) technologies to build such education system. E-education technologies are the most effective tool for managing new types of education and developing the necessary knowledge and skills in the future for lifelong education. E-education creates a bridge between labor activity and education and creates extensive opportunities for lifelong education.

\section{Method}

In recent years, the ways in which people have interacted with each other has undoubtedly changed. The use of public network utilities, such as face-to-face dialogue and telephone conversations, continues to increase. Facebook and Twitter. Nothing is different from this phenomenon. It should be noted that students are not separated from smart phones that can update their status.

Note that today there are considerable improvements in internet resources development in Azerbaijan. The main reason for this is the increased interest of the pedagogical staff in the medium and higher education of 
using the internet as the educational tool. Today, higher education institutions are provided with computer and internet in Azerbaijan. The results of the analyzes show that they are used effectively in the education process. Today's teachers are interested in the development of electronic resources in electronic governance systems. The Azerbaijani state is not indifferent to these issues.

\section{Current Situation}

The State Strategy for the Development of Education in the Republic of Azerbaijan was approved by the Decree 13 of October 24, 2013. The decree states: "In modern times the role of education in economic life has significantly increased.At the moment, education should be accompanied by the introduction of the required knowledge and skills in the economy, as well as the comprehensive training of the person to future life and integration into the society ${ }^{1}$. The most important of all is the factor that raises the role of education in economic life.At the same time, rapid technological advancement requires regular updates of knowledge and skills. This increases the demand for new smart educational technologies and more appropriate qualifications and competitiveness. Based on knowledge, the education system occupies a special place in the development of the economy".

The society of information and knowledge creates enormous opportunities for publicizing the individual knowledge with the help of the Internet.At present, a number of reforms are being carried out in Azerbaijan in the direction of formation of information and knowledge society.Adopted by the Decree of the President of the Republic of Azerbaijan dated December 29, 2012², "Azerbaijan 2020: Outlook for the Future" Development Concept and "Strategic Roadmap for the National Economy Perspective of the Republic of Azerbaijan" approved by Decree of the President of the Republic of Azerbaijan dated December 6, 2016 has been accepted.These state programs also give impulse to the development of other knowledge-based economics infrastructure - high quality education, effective fundamental science, knowledge production and high technologies, effective science-technical business venture, and implementation of ideas and transfer.The important role of e-education in the development of national education systems has been reflected in relevant documents confirmed in our country. Thus, the Law of Republic of Azerbaijan on education "833-IIIQ of June 19, 2009" was approved ${ }^{3}$.

\section{Analysis of Electronic Education System in Azerbaijan and Methods of Their Economic Efficiency Evaluation}

The core of the modern electronic education system is the LMS (Learning Management System) or the training process management system.LMS is designed for a large number of students and focuses on cooperative training in educational institutions. The main feature is the ability of the trainee to pass a certain part of the course, the date of entry into the course, the number of visits, and to control the process of passing the course. This system allows the user to sign up for listening the course.Sends the registered user a reminder of the next online course. The trainee can check his or her own values. Also, has the ability to chat, participate in different social groups.

Here are some examples of electronic education systems currently available around the world:

1. e LEARNING 3000- (eLearning Server 4G + RLS + TinCan API for the mobile training). The program uses more universities. Integrated: BD, Active Directories, Navision, 1C, Lotus, SAP

http://hypermethod.ru/

2. WebTUTOR - (supports the international standarts such asSCORM 1.2, SCORM 2004, AICC, TinCan). Working with İE və Mozilla FireFox browsers. http://websoft.ru/db/wb/root_id/webtutor_sdo/doc.html

3. MOODLE 2.6 - (GNU General Public License) shared by license. Inteqrated: Joomla. 30\% of higher education institutions in US, and Czech, Slovak, Hungarian and Thai schools are using it.

It is known that the implementation of advanced technologies in the education system serves to innovative

${ }^{1}$ Development Concept "Azerbaijan 2020: The View to the Future", 29 December 2012,"State strategy under development of education in Azerbaijan Republic" by Order No.13 dated 24.10.2013. Baku, Azerbaijan. 2013,https://edu.gov.az/en/page/473

${ }^{2}$ National Strategy for the Development of Information Society in the Republic of Azerbaijan for 2014-2020,https://president.az/files/

${ }^{3}$ Huseynova Arzu, Salifova Tarana, Mazanova Ophelya, Estimation of innovation activity of the regions of the Azerbaijan republic. 37 th International Scientific Conference on Economic and Social Development -"Socio Economic Problems of Sustainable Development" Baku, 14-15 February 2019,41-50; Web of Science 
development. The implementation of the LMS system and the Moodle, which has been used to improve the quality of education and dynamic development in our country, has become widespread. Attention is paid to the existing problems and ways to resolve them, discussion of the advantages and perspectives of development, and study the international experience.It is noted that in the modern world, the application of advanced technologies in any field of activity, including education, has a great importance in terms of improving quality in this area, achieving positive quality indicators and dynamic development. It is also noted, that MOODLE LMS is more widely used in the world in comparison with the Blackboard and Sakai LMSs.

At present, the LMS system is implemented in our country. In the UNEC (ASUE), Prometheus has been prepared for 20 observation surveys in the 2015 academic year with 30 teachers and students and 30 secondary education providers in the electronic education system.

As a result, SWOT analysis method was used in the processing of surveys, 2 (two) tables were developed on the general state of teachers and students' use of electronic education system.

Table 1. Analysis of teachers' use of electronic education system

\begin{tabular}{ll}
\hline \multicolumn{1}{c}{ Strong sides } & \multicolumn{1}{c}{ Weak sides } \\
\hline Traditional & Online \\
Hybrid & Offline \\
Socialnet & Forum \\
Webinar & Video-lesson \\
e-lecture & Youtube \\
e-book & Real time mode \\
Work in search systems & Wikipediya \\
& Online-simulation \\
& Use of e-databases on materials \\
\hline
\end{tabular}

Table 2. Analysis of students' use of electronic education system

\begin{tabular}{ll}
\hline \multicolumn{1}{c}{ Strong sides } & \multicolumn{1}{c}{ Weak sides } \\
\hline Online & Traditional \\
Offline & Hybrid \\
Forum & Work in search systems \\
Video-lesson & Webinar \\
Youtube & e-lecture \\
Real time mode & e-book \\
Wikipediya & \\
Online-simulation & \\
Use of e-databases on materials & \\
posted online & \\
Socialnet & \\
\hline
\end{tabular}

As we see from the analysis, students are more interested in using electronic education system than teachers. On the other hand, although many countries around the world are using electronic education system and using the LMS system, the issue of the importance of establishing this system in our country is reflected only in government programs. Establishing the LMS system will result in more benefits for students.

Let's look at the regression model to calculate the effects of survey results on each other. For this purpose we will process the request data after the survey has been completed.

Table 3. Assessment of survey results

\begin{tabular}{ccccc}
\hline $\mathbf{N}$ & e-resources & High school & Middle school & Students \\
& teachers & teachers & & Pupils \\
\hline
\end{tabular}




\begin{tabular}{|c|c|c|c|c|c|}
\hline 1. & Youtube & 14 & 19 & 11 & 17 \\
\hline 2. & Video-lesson & 12 & 21 & 10 & 4 \\
\hline 3. & Webinar & 9 & 3 & 2 & 6 \\
\hline 4. & Forum & 4 & 6 & 2 & 2 \\
\hline 5. & e-book & 30 & 28 & 15 & 24 \\
\hline 6. & e-library & 11 & 8 & 3 & 9 \\
\hline 7. & Wikipediya & 10 & 12 & 8 & 13 \\
\hline 8. & $\begin{array}{l}\text { Real } \\
\text { time mode }\end{array}$ & 10 & 13 & 3 & 14 \\
\hline 9. & e-materials & 11 & 14 & 5 & 6 \\
\hline 10. & sos.net & 24 & 21 & 19 & 8 \\
\hline 11. & $\begin{array}{l}\text { Online- } \\
\text { simulation }\end{array}$ & 8 & 7 & 4 & 8 \\
\hline 12. & Search & 5 & 12 & 7 & 17 \\
\hline 13. & Hybrid & 12 & 25 & 12 & 10 \\
\hline 14. & traditional & 24 & 23 & 23 & 10 \\
\hline 15. & e-base & 10 & 7 & 2 & 10 \\
\hline 16. & e-lecture & 9 & 18 & 6 & 6 \\
\hline 17. & Online & 5 & 8 & 3 & 8 \\
\hline 18. & Offline & 2 & 9 & 6 & 4 \\
\hline 19. & e-mail & 25 & 26 & 16 & 28 \\
\hline 20. & Chat & 29 & 27 & 18 & 30 \\
\hline
\end{tabular}

To ensure the convenience of the processing, let's codify the result parameters in the survey questionnaire and determine the coded informatics indicators. Codify data in survey form as e-resource and divide them into clusters:

Table 4. Grouping of e-resources according to usage level

\begin{tabular}{clcccc}
\hline N & \multicolumn{1}{c}{ e-resources } & $\begin{array}{r}\text { Result indicator } \\
\text { High teacher }\end{array}$ & Middle teacher & Student & Pupil \\
\hline Cluster 1 & (usage levelof network technology) & & & \\
1. & Chat (mob.) & 29 & 27 & 18 & 30 \\
2. & Sos.net & 24 & 21 & 19 & 8 \\
3. & Forum & 4 & 6 & 2 & 2 \\
4. & Webinar & 9 & 3 & 2 & 6 \\
5. & e-mail & 25 & 26 & 16 & 28 \\
6. & Youtube & 14 & 19 & 11 & 17 \\
\hline
\end{tabular}




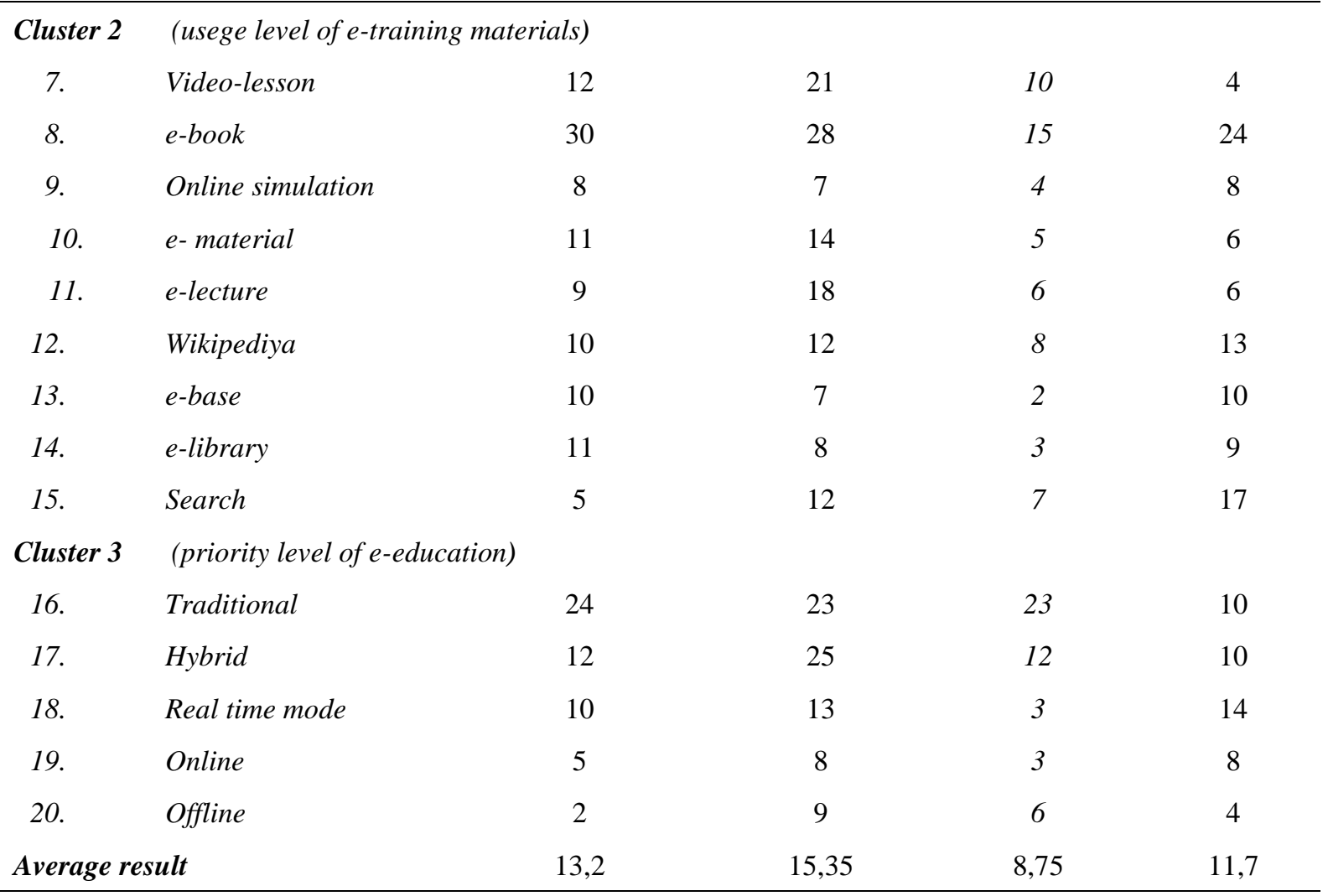

The table summarizes the result indicator and the factor indexes of the e-resources divided into cluster groups.As you can see, the result indicator of the electronic resources listed in Claster 1 and the factor indexes are high.Because 99\% of the population of Azerbaijan is a mobile phone user.There is a disparity between the value of the result indicator and the value of the factor index on electronic resources found in Cluster 2.Thus, the high teacher's parameters value is lower than the factor index value.In the field of education, there is a great need for creative staff, who work with innovations.

Innovation potential in Azerbaijan is weak.Finally, Cluster 3 usage levels of parameters value are quite low. Because, the azerbaijani-language electronic resources are quite low.No methodological resources have been developed for the use of electronic resources in Azerbaijan.Generally, there is no normative legal document in this field.

Thus, the high teacher's index is calculated based on 20 indicators of 3 factor indexes.Here, e-resources differ from each other by the value of factor groups.For example the average values showing the level of use of e-resources on factor groups were calculated and diagram based on it was calculated.

Figure 1. Comparison of factor index.

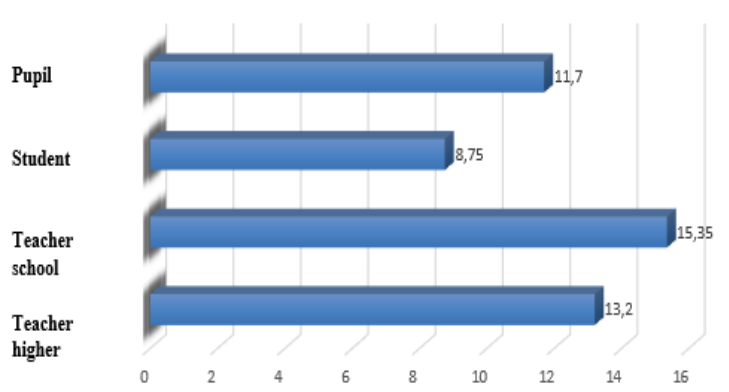

Regression models are set up on the interaction between the middle teacher, student and pupil factors and the high teacher factor of indicators included in the group of factor indixes. As a result, all units became equal. Let's take a 
look at the impact of the survey results on each other.The obtained equality of values and statistics are given in Table 5. The linear regression model is designed for the following indicators:

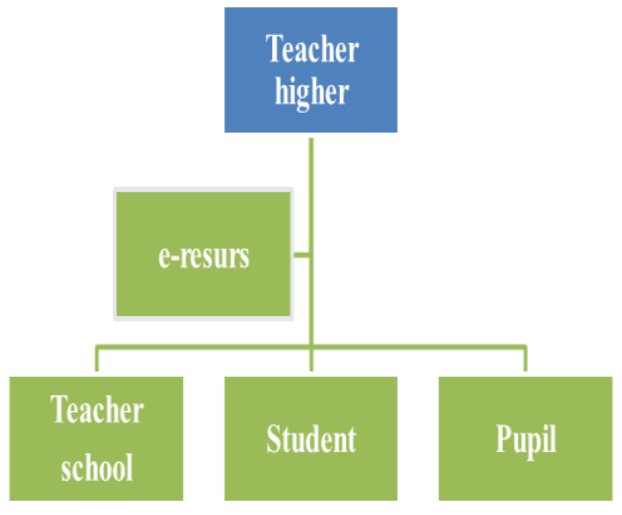

Figure 2. Regression model indicators Interaction between the high teacher's factor and the other 3 (three) factors - the middle teacher, student, and pupil is determined by the index of the use of 20 electronic resources.

Table 5. Linear regression equations for the group of factors

\begin{tabular}{|c|c|c|c|}
\hline $\begin{array}{l}\text { Factor } \\
\text { group }\end{array}$ & Linear regression equation & $\begin{array}{c}\text { Determina } \\
\text { tioncoefficient }\end{array}$ & $\begin{array}{c}\text { Darbin- } \\
\text { Outson coef } \\
\text { ficient }\end{array}$ \\
\hline $\begin{array}{l}\text { Teacher } \\
\text { school }\end{array}$ & $\begin{array}{r}\mathrm{Y}_{\mathrm{i}}=5,1851+0,7701 X i_{\text {Middle }} \\
\text { teacher }\end{array}$ & $\mathrm{R}^{2}=0,6683$ & $\mathrm{DW}=2,11$ \\
\hline Student & $\mathrm{Y}_{\mathrm{i}}=3.0584+0.654 X i_{\text {Student }}$ & $\mathrm{R}^{2}=0,4913$ & $\mathrm{DW}=1,58$ \\
\hline Pupil & $\mathrm{Y}_{\mathrm{i}}=0,1786+0,6494 X i_{\text {Pupil }}$ & $\mathrm{R}^{2}=0,7199$ & $\mathrm{DW}=1,89$ \\
\hline
\end{tabular}

It should be noted that the determinant coefficient depends entirely on the indications of result index value of the high teacher.The determinant coefficient of middle teacher factor indicates that $67 \%$ of high teacher depend on a middle teacher.Darbin-Watson's coefficient is smaller than 2, meaning that autocorrecting is adequate for indicators of equality.The determinant coefficients in the high teacher`s coefficient, middle teacher, student, and student-dependency models show that the high teacher's result indicator depend on the indicators included in the model: at least $49 \%$ of the student factor and $71 \%$ of the pupil factor.

The problem of reducing the usage level of electronic resources by teachers has been identified as a result of the regression model based on the questionnaire survey. To analyze the cause of the problem, we need to use the macro environment analysis, in other words PEST analysis.PEST is a political, economic, social and technological environment. Macro-environment is political, legal, economic, demographic, social, cultural, technological and environmental changes in our society's life. We will look at the economic and political environment together because theinteraction between them makes it difficult to identify individual effects that are often taken separately.Political change in one sphere creates economic change in other spheres, and changes in the economy can accelerate political activities and changes in general.

Table 6 . PEST analysis

\begin{tabular}{llll}
\hline POLITICAL & \multicolumn{2}{c}{ P E S T } & analysis \\
Factor & $\begin{array}{l}\text { Impact on educational } \\
\text { institutions }\end{array}$ & Planned event \\
\hline $\begin{array}{l}\text { State does not provide teachers } \\
\text { with free internet }\end{array}$ & The teacher can not work on it & $\begin{array}{l}\text { Teachers will be given a workshop on } \\
\text { e-mail usage }\end{array}$ & Control over budget spending reduction \\
\hline \begin{tabular}{l} 
IT department is closing \\
\hline
\end{tabular}
\end{tabular}


Low funding from public sector

IT + health

SOCIAL

Rise of salary

\section{TECHNOLOGICAL}

Webcam, networking, social networking and online students
Web demand for web-teacers in online social student groups

Requirement for quality improvement, skilled workers search Demand for employers in Testing of teachers
multi-profile courses

Preparation for distance lessons Preparing graduates for a global career
Appropriate salary

Work experience on Lonardoo / Erasmus schemes

An electronic warehouse that stores educational facilities,

Open Source

Web 2.0 new website for students and teachers to use interactivity

In Table 6, we need to look at all the factors in the PEST analysis and to analyze the impact on their higher education institutions by choosing the important ones, and in the end, the most positive and most negative factor that will affect the university's overall macro environment.PEST analysis was based on questionnaire survey. Strategic conditions created by external environment affecting the low level of use of e-resources by teachers in higher education institutions were assessed.[6]

\section{Conclusions}

The possibilities for e-learning in Azerbaijan are quite complicated. Development of methodology and normative base is at a low level. The uncertainty of the criteria for the quality of electronic courses, complicates the implementation of electron education.

In the course of the study, the current situation has been analyzed and suggestions have been made to address the problem[7].

The efficiency of training on the basis of information resources depends on the quality and quantity of resources and information technologies used by teachers and students. Furthermore, the economic effect of electronic courses depends on the number of students.

Electronic training is offered by the government to provide e-standards for new generation technologies, support broadband effective and other emerging technology systems, accelerate technical work required for the national e-portfolio development, and elaborate electronic education methodological plans.In addition, it is recommended that a strategy for the electron training system be developed to expand the national electron education network and create a system of personnel training on innovative technologies.[8]

\section{REFERENCES}

[1] Development Concept "Azerbaijan 2020: The View to the Future", 29 December 2012, "State strategy under development of education in Azerbaijan Republic" by Order No.13 dated 24.10.2013. Baku, Azerbaijan. 2013. https://edu.gov.az/en/page/473

[2] National Strategy for the Development of Information Society in the Republic of Azerbaijan for 2014-2020. Baku, 02.04.2014.https://president.az/files/

[3] HuseynovaArzu, SalifovaTarana, Mazanova Ophelya, Estimation of innovation activity of the regions of the Azerbaijan republic. 37th International Scientific Conference on Economic and Social Development -"Socio Economic Problems of Sustainable Development" - Baku, 14-15 February 2019,41-50; Web of Science.

[4] HuseynovaArzu, Mazanova, Ophelya, Model evaluation of an Innovative Capital, Conference: 10th AICT, Place: Baku, AZERBAIJAN Publ.: OCT 12-14, 2016, 607-609 Web of Science.

[5] Mehdialiyev, AghaMehdi; Mazanova Ophelia, IEEE. On some problems of the creation and development of green technologies in Azerbaijan. 2013, Web of Science, Google Scholar: 438-442.

[6] Lynne S. Wolbert, Doret J. De Ruyter \& Anders Schinkel. What kind of theory should theory on education for human flourishing be? British Journal of Educational Studies 2017, pp. 1-15 http://edu.gov.az/az/page/72/302

[7] Matthew D. Dean (2016) A call to embrace social reading in higher education, innovations in Education and Teaching International, 53:3, 296-305, http://dx.doi.org/10.1080/14703297.2014.991934

[8] Mayke W. C. Vereijken, Roeland M. van der Rijst, Arnout Jan de Beaufort,Jan H. van Driel\&Friedo W. 
Dekker. Fostering first-year student learning through research integration into teaching: Student perceptions, beliefs about the value of research and student achievement. Innovations in Education and Teaching International.2018; 55: 425-432 